\title{
The effect of the parameters of submerged arc surfacing with oscillating electrode on a padding weld forming, depth of fusion penetration and the content of parent metal in a weld
}

Keywords:

submerged arc surfacing with oscillating electrode; run formation;

inhomogeneity of padding weld metal

\begin{abstract}
The effect of oscillating movement amplitude and frequency of electrode wire swinging on forming of pad weld runs, the character of parent metal penetration, as well as structural and chemical inhomogeneity in the zone of intermixing padding weld with parent material has been tested while submerged arc surfacing using oscillating electrode. It has been stated that along with increasing frequency of electrode wire end oscillations and the same amplitude and surfacing speed, the weld run formation is improved, the width of the zone of padding weld intermixture with parent material is reduced and more dispersive structure with lower structural and chemical inhomogeneity in a padding weld is being formed. More uniform fusion penetration into the parent material and alignment of fusion line can be observed. Those relations remain practically unchanged with increasing amplitude of oscillation.
\end{abstract}

\section{Introduction}

It is known that in some cases, in order to reduce the metal penetration of the material and to obtain wide and relatively short runs, arc welding is carried out with the pendulum movement of the electrode wire or tape $[1 \div 4]$. In these works, fundamental attention was paid to studying the influence of the amplitude and frequency of fluctuations in the electrode wire or tape on the formation of pad weld runs. However, if we take into account the fact of the direct interaction of the welding arc with the parent material during lateral fluctuations of the electrode wire, it should be expected that the character of metal penetration can change along the length of the pad weld runs. As stated earlier [5,6], uneven metal penetration can lead to a decrease in fatigue life of surfaced elements during their operation under cyclic loading conditions.

The analysis shows that if the electrical parameters of the surfacing process are not taken into account, the amplitude and frequency of the electrode wire or tape fluctuations as well as the surfacing speed have a fundamental influence on the above characteristics of pad weld runs. Moreover, all these characteristics are interrelated, and when changing one of them, two other characteristics have to be corrected in order to obtain qualitative pad weld runs.

The purpose of this work was to study the impact of the submerged arc surfacing speed, frequency and amplitude of wire fluctuations on the forming of padding welds, depth and character of metal penetration of the native material, and coefficient of the contribution of native material in the surfaced layer (degree of mixing $\mathrm{Y}$ ).

In the further part of the article, the term is used: intermixing of the padding weld with parent material (also referred to as transition zone, fused zone, mixing zone) - this is a zone with variable chemical composition, which arises due to a significant difference in the chemical composition of the combined materials. The chemical composition of the padding weld at the border with the base material changes stepwise.

prof. dr hab. inż. Igor A. Riabcew, Anatolij A. Babiniec, Iwan P. Lentjugow - E.O. Paton Electric Welding Institute of the National Academy of Sciences, Kiev, Ukraine;

Corresponding author. ryabtsev39@gmail.com 
Table I. The effect of surfacing speed, amplitude A and oscillation of electrode wire frequency $\mathrm{N}$ on the dimensions of surfaced runs and ratio of mixture $y$

\begin{tabular}{|c|c|c|c|c|c|c|c|}
\hline \multirow{2}{*}{ Sample no } & \multicolumn{2}{|c|}{ Fluctuations } & \multirow{2}{*}{$\begin{array}{l}\text { Surfacing } \\
\text { speed, } m / h\end{array}$} & \multicolumn{3}{|c|}{ Dimensions of the runs, $\mathrm{mm}$} & \multirow{2}{*}{$v, \%$} \\
\hline & A, $\mathrm{mm}$ & $\mathrm{N}, \min ^{-1}$ & & Width & Height & $\begin{array}{c}\text { Amount } \\
\text { of penetration }\end{array}$ & \\
\hline 1 & 25 & 28 & 7 & 38.8 & 3.4 & 1.7 & 39 \\
\hline $2^{*}$ & 25 & 45 & 7 & 36.4 & 2.95 & 1.6 & 37 \\
\hline 3 & 40 & 18 & 7 & 46.8 & 2.05 & 1.8 & 54 \\
\hline 4 & 40 & 32 & 7 & 47.0 & 1.8 & 1.5 & 50 \\
\hline 5 & 25 & 28 & 10 & 37.5 & 1.9 & 1.8 & 55 \\
\hline 6 & 25 & 45 & 10 & 35.8 & 2.7 & 1.5 & 52 \\
\hline 7 & 40 & 18 & 10 & 42.6 & 2.1 & 1.5 & 50 \\
\hline 8 & 40 & 32 & 10 & 44.7 & 1.5 & 1.4 & 49 \\
\hline
\end{tabular}

\section{Technological conditions of surfacing}

The tests were carried out using PP-Np-25H5FMS fluxcored wire (ПП-Нп-25Х5ФМС) according to GOST 26101-84 (EN $14700 \mathrm{~T}$ Fe8 classification) with a diameter of $2.6 \mathrm{~mm}$ and AN-26 flux (AH-26) according to GOST 9087-81. The chemical composition of the weld metal corresponds to the tool steel 25H5MSGF. Parameters of surfacing: current intensity $320 \mathrm{~A}$, arc voltage $32 \mathrm{~V}$, wire feed speed $-3.0 \mathrm{~m} / \mathrm{min}$, wire extension $-20 \mathrm{~mm}$, surfacing speed $(\mathrm{Vn})-7$ and $10 \mathrm{~m} / \mathrm{h}$, frequency of fluctuations $(\mathrm{N})-18 ; 28 ; 32$ and $45 \mathrm{~min}^{-1}$; amplitude of fluctuations (A) -25 and $40 \mathrm{~mm}$. The tests were carried out on eight samples of S235JR steel of identical dimensions (Tab. I).

\section{Process and results of the tests}

The beginning and the section with the crater were cut off from the pad weld runs. Next, longitudinal and transverse macrospecimens were made from each pad weld run to determine the dimensions of runs, the degree of mixing $y$ and to study macro- and microstructure of runs. Dimensions of all tested runs, determined on transverse macrospecimens with an accuracy of $0.1 \mathrm{~mm}$ (average value of $5 \div 7$ measurements) and degree of mixing are given in Table $\mathrm{I}$.

The minimum degree of mixing at $37 \div 39 \%$ was found in samples 1 and 2, amount of penetration $-1.6 \div 1.7 \mathrm{~mm}$. Smaller penetration $-1.4 \div 1.5 \mathrm{~mm}$, found in samples 7 and 8 , but the degree of mixing is $49 \div 50 \%$.

The tests have shown that, according to the total assessment of the dimensions of pad weld runs and the degree of mixing, samples 2 surfaced at a speed of $7 \mathrm{~m} / \mathrm{h}$, fluctuation amplitude of $A=25 \mathrm{~mm}$, and fluctuation frequency of $\mathrm{N}=45 \mathrm{~min}^{-1}$ had the best indicators (see Tab. I).

Figures 1 and 2 present the macrostructure of longitudinal specimens of pad weld runs made at the speed of 7 and $10 \mathrm{~m} / \mathrm{h}$, with different frequency and amplitude of fluctuations. At a surfacing speed of $7 \mathrm{~m} / \mathrm{h}$, increasing the frequency of fluctuations in the electrode wire makes it possible to obtain a more even penetration and a more fluid line of padding weld penetration with the parent material (Fig. 1b and 1c). The most even penetration line is observed in sample 2 , surfaced at fluctuation amplitude of $25 \mathrm{~mm}$ and a maximum frequency of $45 \mathrm{~min}^{-1}$ (Fig. 1b).
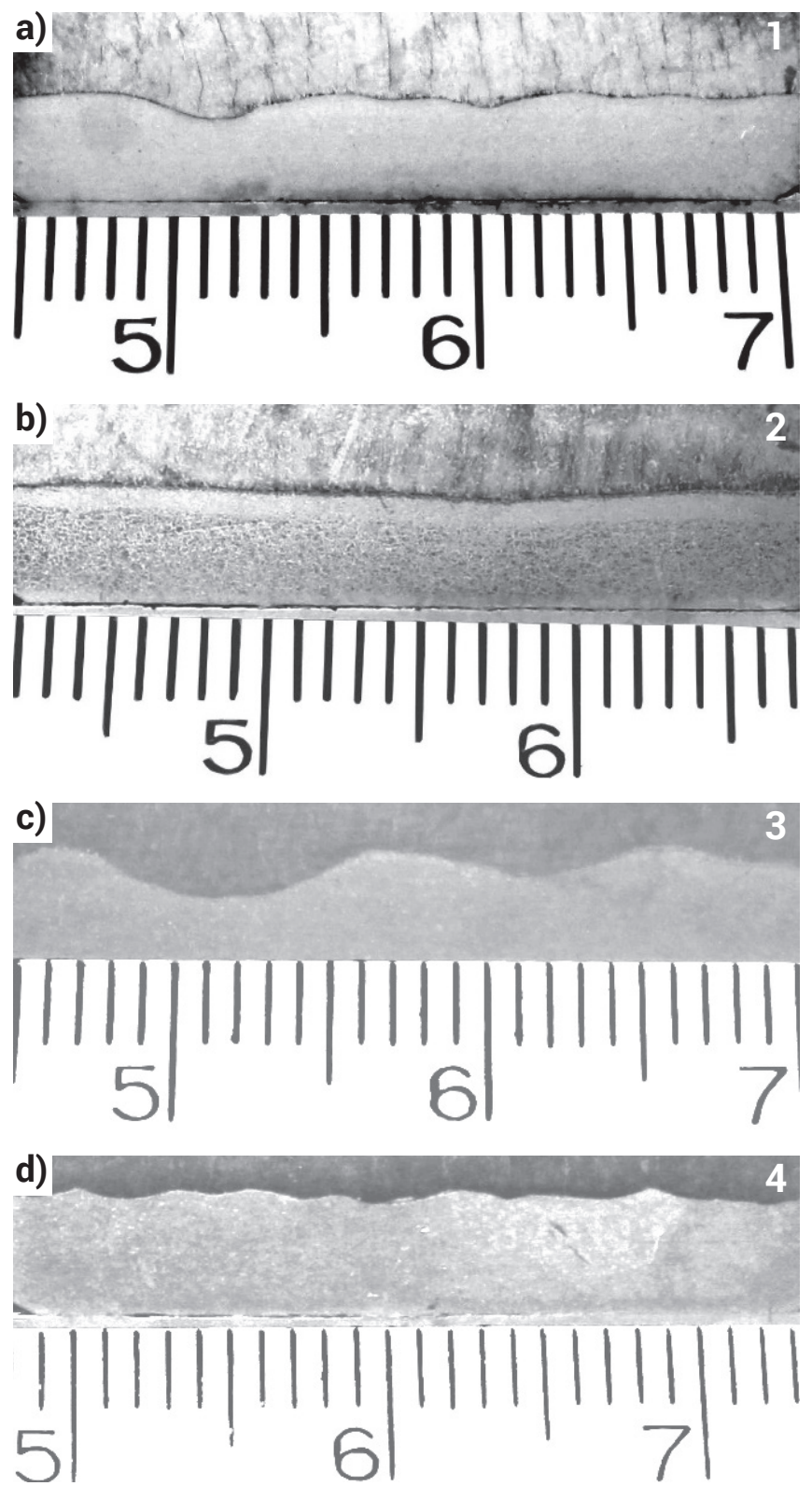

Fig. 1. Longitudinal macroscopic microsections of samples surfaced with speed of $7 \mathrm{~m} / \mathrm{h}$ : a) sample $1: A=25 \mathrm{~mm} ; \mathrm{N}=28 \mathrm{~min}^{-1} ; \mathrm{b}$ ) sample 2 : $A=25 \mathrm{~mm} ; \mathrm{N}=45 \mathrm{~min}^{-1} ; \mathrm{c}$ ) sample $3: A=40 \mathrm{~mm} ; \mathrm{N}=18 \mathrm{~min}^{-1} ; \mathrm{d}$ ) sample 4: $A=40 \mathrm{~mm} ; \mathrm{N}=32 \mathrm{~min}^{-1}$. Samples numeration - see Table I 

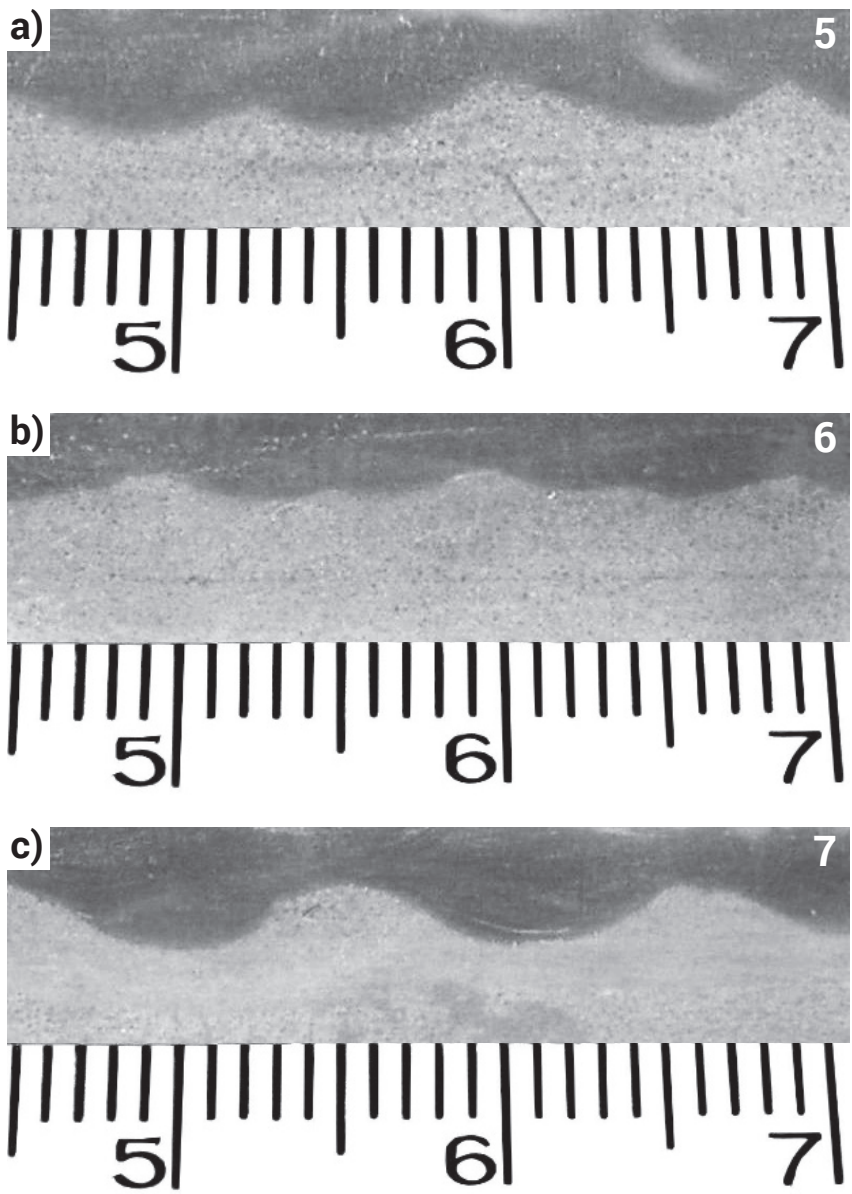

d)

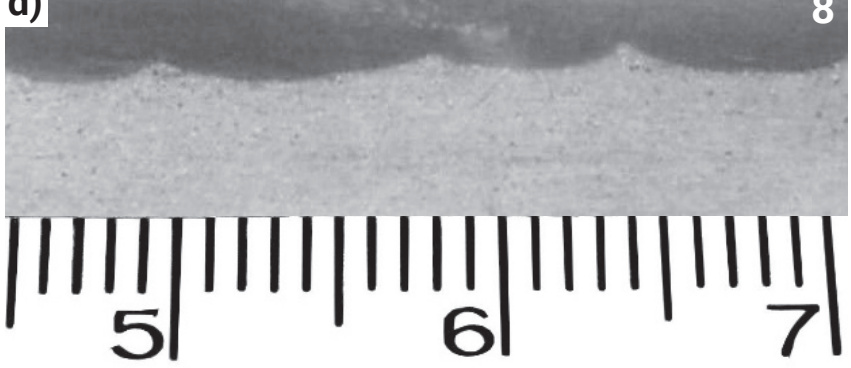

Fig. 2. Longitudinal macroscopic microsections of samples surfaced with speed of $10 \mathrm{~m} / \mathrm{h}$ : a) sample 5 : $\left.A=25 \mathrm{~mm} ; \mathrm{N}=28 \mathrm{~min}^{-1} ; b\right)$ sample 6: $A=25 \mathrm{~mm} ; \mathrm{N}=45 \mathrm{~min}^{-1}$; c) sample $7: A=40 \mathrm{~mm} ; \mathrm{N}=18 \mathrm{~min}^{-1}$; d) sample 8: $A=40 \mathrm{~mm} ; \mathrm{N}=32 \mathrm{~min}^{-1}$. Samples numeration - see Table I
With an increase in the surfacing speed up to $10 \mathrm{~m} / \mathrm{h}$, an even penetration was not obtained at any frequency and amplitude of fluctuations in the electrode wire (Fig. 2a to 2d). At the same time, during the welding with increased speed $(10 \mathrm{~m} / \mathrm{h})$, the increase in the frequency of electrode wire fluctuations also promotes a more even penetration and greater "smoothness" of the fusion line (Fig. 2b and 2c), however this effect is lower than at the surfacing speed of $7 \mathrm{~m} / \mathrm{h}$.

Investigation of the microstructure of the padding weld of sample no $1\left(\mathrm{Vn}=7 \mathrm{~m} / \mathrm{h}, \mathrm{A}=25 \mathrm{~mm}, \mathrm{~N}=28 \mathrm{~min}^{-1}\right)$ showed that it has a dendritic structure (Fig. 3a). In the near-surface layers of padding weld a microstructure of cellular structure prevails, with an average grain diameter of $60 \div 80 \mu \mathrm{m}$. The hardness of the matrix material, determined by the Vickers method according to GOST 9450-76, is HV1 $=5420 \div 6060 \mathrm{MPa}$ (martensite + carbides). The hardness of the matrix material, determined by the Vickers method according to GOST 945076 , is $\mathrm{HV} 1=5420 \div 6060 \mathrm{MPa}$ (martensite + carbides).

At the crystallite boundary there is a precipitation of spherical carbide chains (Fig. 3b). The structure of the surfaced metal of sample no $2\left(\mathrm{Vn}=7 \mathrm{~m} / \mathrm{h}, \mathrm{A}=25 \mathrm{~mm}, \mathrm{~N}=45 \mathrm{~min}^{-1}\right)$ - dendritic-cellular with a predominance of cellular (Fig. 3c), with a mean diameter of crystallites of $30 \div 40 \mu \mathrm{m}$. With the fusion line in the native material the structure becomes dendritic. The width of crystallites in this zone is $70 \div 90 \mu \mathrm{m}$. Hardness of the matrix material HV1 $=4880 \div 5480 \mathrm{MPa}$. At the crystallite boundaries, as well as in sample no 1, spherical finely dispersive carbides are released (Fig. 3d). The HAZ has a width of $3600 \mu \mathrm{m}$.

The microstructure of the padding weld metal of sample no $3\left(\mathrm{Vn}=7 \mathrm{~m} / \mathrm{h}, \mathrm{A}=40 \mathrm{~mm}, \mathrm{~N}=18 \mathrm{~min}^{-1}\right)$ - dendritic-cellular with a cellular predominance on the surface (Fig. 4b). The average cell diameter is $50 \div 60 \mu \mathrm{m}$. Hardness of the matrix material - HV1 = 6060 $\div 6130 \mathrm{MPa}$. A martensite band was observed at the fusion line from the padding weld side. Martensite in this zone is formed in the form of large needles. The width of crystallites at the fusion line is $70 \div 80 \mu \mathrm{m}$. Width of $\mathrm{HAZ}-2100 \mu \mathrm{m}$.

The padding weld of sample no $4(\mathrm{Vn}=7 \mathrm{~m} / \mathrm{h}, \mathrm{A}=40 \mathrm{~mm}, \mathrm{~N}$ $=32 \mathrm{~min}^{-1}$ ) also has a dendritic-cellular structure, with a cellular form predominance on the surface. Diameter of the cells is $40 \div 50 \mu \mathrm{m}$ (Fig. $4 \mathrm{~b}$ and $4 \mathrm{~d}$ ). At the fusion line - dendritic structure, the width of crystallites in this area is $60 \div 80 \mu \mathrm{m}$. The hardness of the crystalline matrix in a given area is lower than in sample No. 3 and is HV1 $=5140 \div 5420 \mathrm{MPa}$. Width of $\mathrm{HAZ}-1800 \mu \mathrm{m}$.
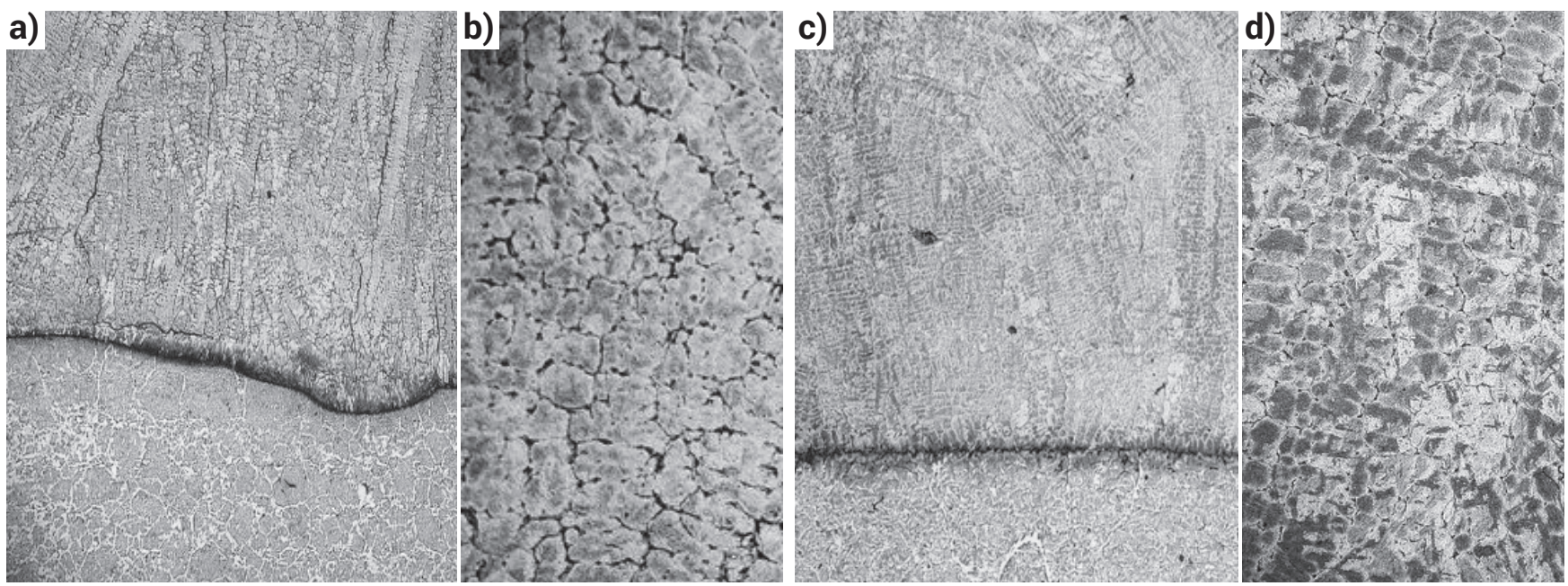

Fig. 3. Microstructure of padding weld samples $1(a, b)$ and $2(c, d)$ : a, $c$ - fusion penetration zone, $x 20 ; b$, $d$ - padding weld metal, $x 100$. Electrolytic etching in chromic acid. $U_{x x}=20 \mathrm{~V} ; t=3 \div 5 \mathrm{~s}$. Samples numeration - see Table I 

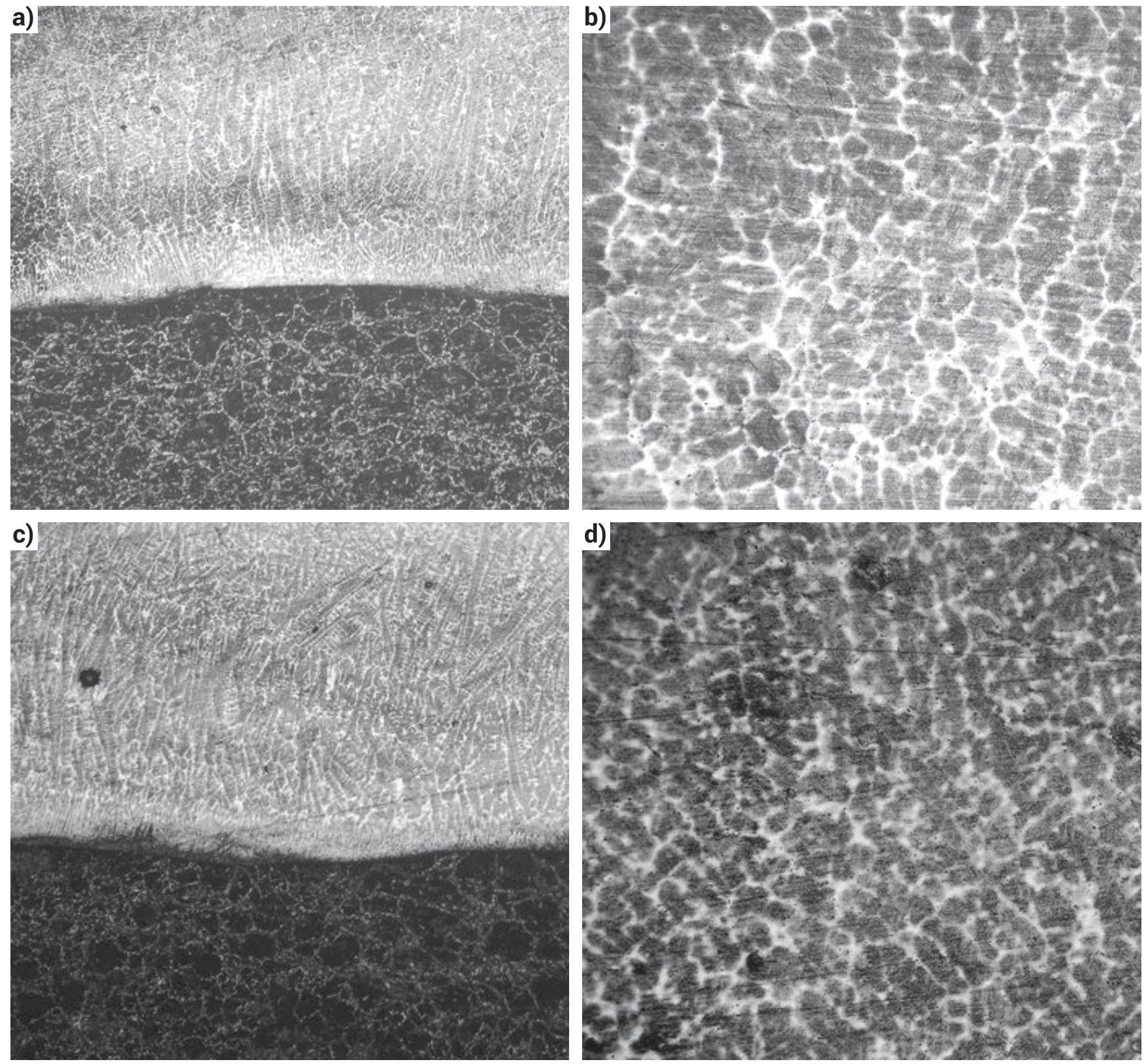

Fig. 4. Microstructure of padding weld samples $3(a, b)$ and $4(c, d)$ : a, c - fusion penetration zone, $x 20 ; b, d$ - padding weld metal, $x 100$. Electrolytic etching in chromic acid. $U_{x x}=20 \mathrm{~V} ; t=3 \div 5 \mathrm{~s}$. Samples numeration - see Table I

Examination of the microstructure of sample no $5(A=25 \mathrm{~mm}$, $\mathrm{Vn}=10 \mathrm{~m} / \mathrm{h}, \mathrm{N}=28 \mathrm{~min}^{-1}$ ) showed that it has a dendritic structure (Fig. 5b). The cellular structure prevails in the near-surface layers of padding weld, with an average diameter of $60 \div 80 \mu \mathrm{m}$. The hardness of the matrix is HV1 $6860 \mathrm{MPa}$ (martensite). Diameter of the cells in the upper part of the padding weld is $15 \div 20 \mu \mathrm{m}$; width of crystallites $\mathrm{h}-15 \div 25 \mu \mathrm{m}, \mathrm{HAZ}-1200 \mu \mathrm{m}$.

The microstructure of the sample no $6(\mathrm{Vn}=10 \mathrm{~m} / \mathrm{h}, A=25 \mathrm{~mm}$, $\mathrm{N}=45 \mathrm{~min}^{-1}$ ) are shown in figures $5 \mathrm{c}$ and $5 \mathrm{~d}$. It also has a dendritic structure with a cellular structure in the near-surface layers. Diameter of the cells $-25 \div 35 \mu \mathrm{m}$; width of crystallites $\mathrm{h}-25 \div 50 \mu \mathrm{m}, \mathrm{HAZ}-800 \div 900 \mu \mathrm{m}$. There are precipitations of intermetallic phases and carbides on the boundaries of crystallites and cells. Microhardness HV1 $6810 \mathrm{MPa}$ in a bright layer and HV1 $6340 \mathrm{MPa}$ in a dark layer.

Examination of the microstructure of sample no $7(\mathrm{Vn}=10 \mathrm{~m} / \mathrm{h}$, $A=40 \mathrm{~mm}, \mathrm{~N}=18 \mathrm{~min}^{-1}$ ) showed that it has a dendritic structure (Fig. $6 a$ and b). Diameter of the cells $-40 \div 60 \mu \mathrm{m}$; Crystallite crystallite width $-40 \div 60 \mu \mathrm{m}, \mathrm{HAZ}-1000 \div 1200 \mu \mathrm{m}$. Microhardness - HV1 $6420 \mathrm{MPa}$. There are precipitations at the boundaries of crystallites and cells, but there are far fewer of them than in the samples shown in Figure 5.
The microstructure of the padding weld metal of the sample no $8\left(\mathrm{Vn}=10 \mathrm{~m} / \mathrm{h}, \mathrm{A}=40 \mathrm{~mm}, \mathrm{~N}=32 \mathrm{~min}^{-1}\right)$ is also dendritic-cellular (Fig. $6 \mathrm{c}$ and $6 \mathrm{~d}$ ). Diameter of the cells $-15 \div 30 \mu \mathrm{m}$; width of crystallites $\mathrm{h}-30 \div 40 \mu \mathrm{m}, \mathrm{HAZ}-600 \div 800 \mu \mathrm{m}$. The chemical and structural inhomogeneity of the $25 \mathrm{H} 5 \mathrm{FMS}$ type alloy surfaced on S235JR steel was examined by microrentgenospectral analysis, X-ray diffraction analysis and metallographic analysis. The results of the microrentigenospectral analysis of the alloying elements showed that the width of the fusion zone with the base material (transition zone) decreases with the increase of the frequency of fluctuations (Tab. II). With a surfacing speed of $7 \mathrm{~m} / \mathrm{h}$, electrode wire fluctuation frequency $\mathrm{N}=28 \mathrm{~min}^{-1}$ and amplitude $A=25 \mathrm{~mm}$, the width of the transition zone is $35 \div 40 \mu \mathrm{m}$, and at $\mathrm{N}=45 \mathrm{~min}^{-1}$ $-20 \div 25 \mu \mathrm{m}$ (Tab. II , samples $1 \div 4$ ). At $A=40 \mathrm{~mm}$ and frequencies $\mathrm{N}=18 \mathrm{~min}^{-1}$ and $\mathrm{N}=32 \mathrm{~min}^{-1}$, the width of the transition zone is $30 \div 35 \mu \mathrm{m}$ and $15 \div 20 \mu \mathrm{m}$.

In the fused zone there is a smooth change in concentration, the chemical heterogeneity of the weld metal is insignificant and amounts to $\mathrm{Cr}_{\max } / \mathrm{Cr}_{\min }=1.23 \div 1.47$ for chromium, and $\mathrm{Mo}_{\max } / \mathrm{Mo}_{\min }=1.21 \div 1.31$ for molybdenum. Increasing the frequency of fluctuations in the electrode wire favors obtaining 

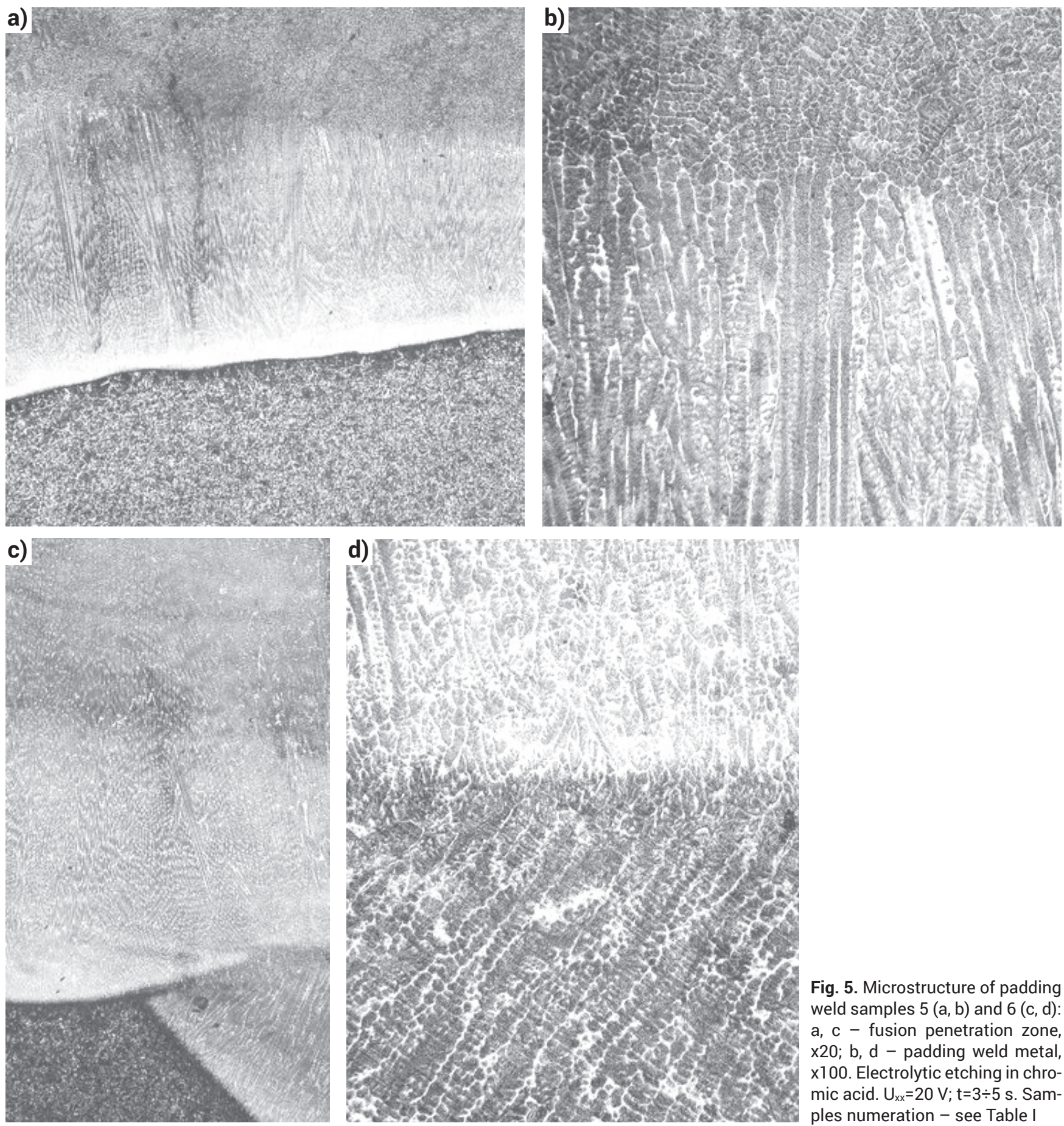

Fig. 5. Microstructure of padding weld samples $5(a, b)$ and $6(c, d)$ : a, c - fusion penetration zone, $x 20 ; b, d-$ padding weld metal, $x 100$. Electrolytic etching in chromic acid. $U_{x x}=20 \mathrm{~V} ; t=3 \div 5 \mathrm{~s}$. Samples numeration - see Table I

Table II. Effect of oscillation electrode surfacing parameters on the microstructure and chemical inhomogeneity of samples $1 \div 8$

\begin{tabular}{|c|c|c|c|c|c|c|c|c|}
\hline \multirow{2}{*}{$\begin{array}{l}\text { Sample } \\
\text { no }\end{array}$} & \multicolumn{3}{|c|}{ Surfacing conditions } & \multicolumn{3}{|c|}{ Microstructural state parameters } & \multicolumn{2}{|c|}{$\begin{array}{l}\text { Indicators of chemical heterogeneity } \\
\text { according to } \mathrm{Cr} \text { and } \mathrm{Mo}\end{array}$} \\
\hline & $\begin{array}{l}\mathrm{Vn}, \\
\mathrm{m} / \mathrm{h}\end{array}$ & $\begin{array}{c}\text { A, } \\
\mathrm{mm}\end{array}$ & $\begin{array}{c}\mathbf{N}, \\
\min ^{-1}\end{array}$ & $\begin{array}{c}d_{\text {komórk }}, \\
\mu m\end{array}$ & $\begin{array}{l}\text { Width of the } \\
\text { transition zone, } \mu \mathrm{m}\end{array}$ & $\begin{array}{l}\text { Microhardness } \\
\text { HV1, MPa }\end{array}$ & $\mathrm{Cr}_{\max } / \mathrm{Cr}_{\min }$ & $\mathrm{Mo}_{\max } / \mathrm{Mo}_{\min }$ \\
\hline 1 & 7 & 25 & 28 & $60 \div 80$ & $35 \div 40$ & $5420 \div 6060$ & $4.5 / 3.4=1.32$ & $0.32 / 0.25=1.28$ \\
\hline $2^{*}$ & 7 & 25 & 45 & $30 \div 40$ & $20 \div 25$ & $5420 \div 5480$ & $4.8 / 3.9=1.23$ & $0.40 / 0.33=1.21$ \\
\hline 3 & 7 & 40 & 18 & $50 \div 60$ & $30 \div 35$ & $6060 \div 6130$ & $3.4 / 2.3=1.47$ & $0.42 / 0.32=1.31$ \\
\hline 4 & 7 & 40 & 32 & $40 \div 50$ & $15 \div 20$ & $5140 \div 5400$ & $3.1 / 2.2=1.41$ & $0.35 / 0.28=1.25$ \\
\hline 5 & 10 & 25 & 28 & $25 \div 35$ & $35 \div 40$ & 6800 & $4.2 / 3.1=1.35$ & $0.41 / 0.30=1.36$ \\
\hline 6 & 10 & 25 & 45 & $15 \div 20$ & $20 \div 25$ & $6700 \div 6800$ & $4.6 / 3.2=1.44$ & $0.38 / 0.30=1.26$ \\
\hline 7 & 10 & 40 & 18 & $40 \div 60$ & $30 \div 35$ & $6400 \div 6300$ & $3.8 / 2.9=1.31$ & $0.42 / 0.34=1.23$ \\
\hline 8 & 10 & 40 & 32 & $15 \div 30$ & $15 \div 20$ & $6340 \div 6810$ & $3.5 / 2.4=1.46$ & $0.34 / 0.28=1.21$ \\
\hline
\end{tabular}



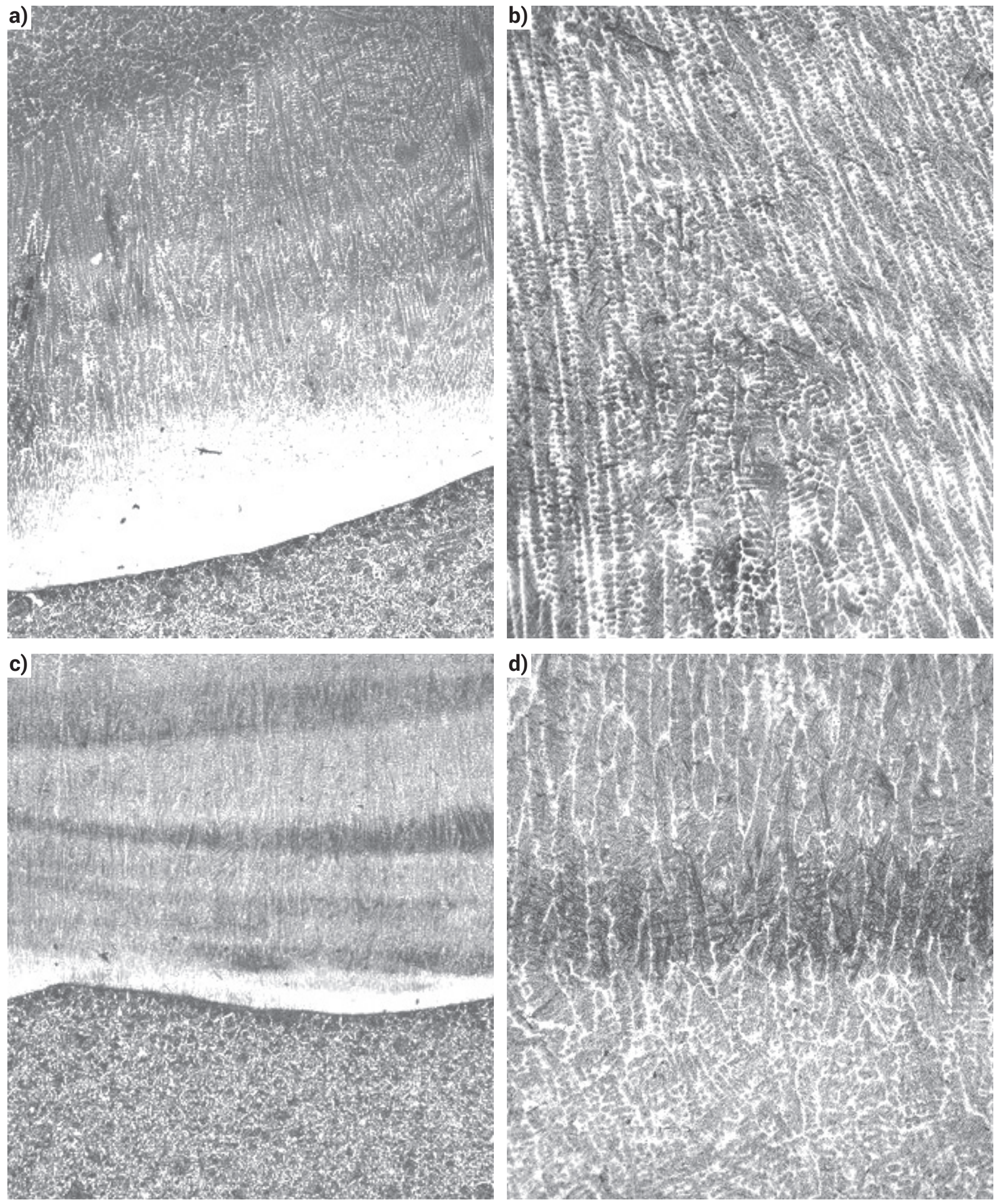

Fig. 6. Microstructure of padding weld samples $7(a, b)$ and $8(c, d): a, c-$ fusion penetration zone, $x 20 ; b, d-$ padding weld metal, $x 100$. Electrolytic etching in chromic acid. Uxx $=20 \mathrm{~V} ; \mathrm{t}=3 \div 5 \mathrm{~s}$. Samples numeration - see Table I

a dispersive structure, a more even distribution of alloying elements, a more "smoothed" fusion line, as well as increasing the homogeneity of the chemical composition of the surfaced metal. The hardness of the matrix is $5140 \div 6060 \mathrm{MPa}$. In the surfaced samples, $\mathrm{Cr}_{7} \mathrm{C}_{3}$ and $\mathrm{Fe}_{3} \mathrm{C}$ carbides, as well as intermetallic phases of the $\mathrm{Mo}_{5} \mathrm{Cr}_{6} \mathrm{Fe}_{18}$ type were found.

With the increase of the surfacing speed to $10 \mathrm{~m} / \mathrm{h}$ a similar relationship is observed (Tab. II, samples $5 \div 8$ ). Increasing the frequency of fluctuations reduces the width of the transition zone, the chemical heterogeneity of the weld metal is $\mathrm{Cr}_{\max } / \mathrm{Cr}_{\min }=1.31 \div 1.46$ for chromium, and $\mathrm{Mo}_{\max } / \mathrm{Mo}_{\min }=1.21 \div 1.36$ for molybdenum. The matrix hardness in this case is slightly higher and amounts to $6340 \div 6810 \mathrm{MPa}$. 


\section{Conclusions}

The tests carried out on the influence of the submerged arc surfacing with oscillating electrode on the padding weld properties have shown that as the frequency of fluctuations in the electrode wire increases, at the same amplitude of the oscillating movements and the surfacing speed:

- surfacing formation is improved;

- the homogeneity of the chemical composition of the surfaced metal increases, and the more dispersive structures are obtained;

- the width of the fusion zone with the parent material is reduced;

- a more even distribution of alloying components occurs;

- there is a more even penetration and "alignment" of the fusion zone of padding weld with the parent material.

It should be noted that these relationships practically do not change as the amplitude of fluctuations increases. Optimal parameters of padding weld forming, penetration depth and degree of mixing as well as structural and chemical homogeneity are ensured in test conditions at the frequency of electrode wire fluctuations of $\mathrm{N}=45 \mathrm{~min}^{-1}$, amplitude $\mathrm{A}=25 \mathrm{~mm}$ and welding speed of $\mathrm{Vn}=7 \mathrm{~m} / \mathrm{h}$.

\section{Literatura}

[1] Данильченко Б.В., Шимановский В.П., Ворончук А.П., Терпило В.Н.: Наплавка быстроизнашивающихся деталей самозащитными порошковыми лентами, Автоматическая сварка, № 5, с. 38-41, 1989.

[2] Гулаков С.В., Бурлака В.В.: Механизм колебания электрода для формирования наплавляемых валиков сложной формы, Вестник Приазовского государственного технического университета, Технические науки, Вып. 20, с. 181-186, 2010.

[3] Спиридонов Н.В., Кудина А.В., Кураш В.В.: Электродуговая наплавка металлоповерхностей колеблющимся электродом в среде защитного газа, Наука и техника, № 4, с. 3-8, 2013.
[4] Goloborodko Zh.G., Dragan S.V., Simutenkov I.V.: Automatic submerged arc surfacing of structural steels with transverse high-frequency movements of electrode, The Paton Welding Journal, N 6, pp. 34-37, 2013.

[5] Рябцев И.А., Бабинец А.А.: Усталостная долговечность многослойных наплавленных образцов, Сварочное производство, № 4, с. 15-19, 2015.

[6] Babinets A.A., Ryabtsev I.A., Kondratiev I.A., Ryabtsev I.I., Gordan G.N.: Investigation of thermal resistance of deposited metal designed for restoration of mill roll, The Paton Welding Journal, N 5, pp. 16-20, 2014. 